\title{
Factors that May Stimulate Entrepreneurship in Tunisian SMEs
}

\author{
Morched Salim ${ }^{1}$, Jarboui Anis ${ }^{2}$ \\ ${ }^{1}$ Doctorant en sciences de gestion, Faculté des Sciences Economiques et de Gestion de Sfax, Rue d'aéroport, 3018 Sfax-TUNISIE \\ ${ }^{2}$ Professeur agrégé de l'enseignement supérieur- Directeur ISAAS, Adresse : ISAAS, BP 1013- 3018 Sfax-Tunisie
}

\begin{abstract}
This research aims to paint a picture of intrapreneurship in Tunisia to lift the factors that can stimulate intrapreneurship in Tunisian SMEs. And, through the description of the characteristics of entrepreneurs and their businesses and raise the various factors that can stimulate. The survey was conducted with a sample of 60 entrepreneurs in the Tunisian regime.
\end{abstract}

Keywords: Intrapreneuriat, Intrapreneurs, entrepreneuriat, Innovation, PME, Gestion

\section{Introduction}

Development intrepreneuriaux behavior has become essential for many businesses who want assured their competitive position through innovation (Russell, 1999). They are increasingly numerous to want establish favorable management practice Outbreak the entrepreneurial spirit in their use, so as to stand by a flexible and constant adaptation now considered imperative to ensure that innovation as the stresses and Chittipeddi Wallet in 1991, and Shatzer Schwartez 1991.

Similarly Filion, (199) this quest of intrapreneurship as an essential condition for success; According to him, only inrapreneurship organizations can survive in a competitive environment increasingly fierce

We are in very emerging fields. It should also be mentioned that many authors were interested in the phenomenon intrapreneurship and tried to clarify the concepts and reflect on the different forms of development of these concepts.

Intrapreneurship the dynamic has always been regarded as an avenue to foster the development of new products, new ways and for new markets. Over time, the use of intrapreneurship activities has become essential to stimulate the process of innovation in all activities and management functions within organizations. Torres (2000: 67) writes that in such a context, large enterprises whose resources traditionally allowed them to act further, feel more and more as the need to act quickly. However, SMEs whose mode of organization and structures traditionally allowed them to act quickly, gradually also feel the need to act further. In one case as in the other, conventional methods of organization that prevailed unchallenged until recently are no longer adapted to the new realities of the environment in which the business moves. By erasing the traditional boundaries between SMEs and large enterprises in terms of agility raw and geographic reach of seconds, these distorted elements spatial and temporal expansion contraction - have in turn exacerbated the competition by blowing natural protections traditional markets.

For Brenner and Brenner (1988: 2) have seen their side the encouragement of innovation and risk taking within firms "has become even hotter with the advent of 'freer trade in both Western Europe and between the United States and Canada, the competition has become more virulent and we increasingly need managerial and technical innovations to survive. " This research proposes to determine the factors that can stimulate intrapreneurship in Tunisian SMEs.

\section{Entrepreneurship and Intrapreneurship}

The two terms overlap in many ways and have many similarities.

The definition of intrapreneur is far from clear. For example, Carrier (1993) rightly pointed out that the discourse on intrapreneurship is a "polyphonic speech" and that the concept of intrapreneur "remains surrounded by a lot of ambiguity we end up not knowing what exactly is referred when talking about intrapreneurship ". It defines it as "the implementation of an innovation by an employee, group of employees or individuals working under the company's control.

They also call for three definitions of the phenomenon that equates Vesper intrapreneurship to a new strategic direction; an innovation from below; and the creation of an autonomous business. Lombardi (1990: 26), "a true intra customer is one who manages his section of the case as if it were his own, that takes real pride in his responsibilities and manages every situation as if his paycheck depended the result. It shows the same commitment and the same approach to business that the entrepreneur. "

Beaucourt and Louart (2000) define their side intra lessee as simply being an employee to business conduct. In the same vein, and Antoncic Hisrich (2001: 498) define intrapreneurship as "entrepreneurship within an existing organization. It refers to an ongoing process within an existing firm regardless of its size and not only led to new business (business ventures) but also to other innovative activities and orientations as the development of new products, services, technology, business administration, competitive strategies and positions "

Entrepreneurship can be defined as an activity involving the discovery, evaluation and exploitation of opportunities. 


\section{International Journal of Science and Research (IJSR) \\ ISSN (Online): 2319-7064 \\ Index Copernicus Value (2013): 6.14 | Impact Factor (2015): 6.391}

Indeed, entrepreneurship aims to introduce new goods and services; new organizational structures; new markets, processes, and materials in ways that did not exist before. For Kirzner, 1973 the entrepreneurial ideas are profit opportunities that were previously passed unnoticed. Entrepreneurs act on these ideas and the economy becomes more productive. Entrepreneurship is considered a key instrument for improving competitiveness among nations, promote economic growth and increase employment opportunities. Researchers and policy makers agree that an entrepreneurial economy is a dynamic and innovative economy, that is to say that experiments with new ideas and new products or processes allowing it to renew itself.

The three major streams of entrepreneurship theory are those of J. Schumpeter, 1934 that define entrepreneurship as the ability to introduce innovations, WJ Baumol, 1968, which considers the productive entrepreneurship is favored by incentives for entrepreneurs to focus on productive innovation and DJ Storey, 1991, admits that the discovery of an opportunity is the central element of entrepreneurship.

\section{Research on Entrepreneurship}

An important current research tries to identify the personal characteristics associated with entrepreneurs and intrapreneurs and highlighted by Matthews et al., 2001

The first study in the field of entrepreneurship emphasizes the individual (Low and Mascmillan 1988). Thus the study of Matthews and Al (2001) was the subject of a study comparing personal characteristics of entrepreneurs, despite several similar characteristic, they were recognized as emerging intrapreneurs perceive months of uncertainty have $\mathrm{d}$ the advantage of risk appetite, develop more formal business plans and more moderate growth expectations that emerging entrepreneurs. Carrier has also compared entrepreneurs and intrapreneurs highlighting their deferred action contexts demanding different skills. For example, because of certain independence and less autonomy, intrapreneurs must demonstrate political skills (persuasion) more important than the entrepreneur.

A study of Brazeal and Wæver (1990) as Winslow (1990) is lean on intrapreneur's motivators. According to them a climate of spontaneity and experimentation, generated by a confident leadership potential and skills of all employees is an essential key to motivate entrepreneurial behavior.

The second current focus on intrapreneurship as organizational process

A larger number of researchers interested in the process of intrapreneurship to its emergence factors and its conditions of realization.

Carrier (1994) demonstrated in a comparative study of intrapreneurship in SMEs and large business, differences in terms of structural and relational contexts and in terms of rewards offered, strategic processes involved and in terms of consequences dissatisfactions intrapreneurs. Indeed, the study shows that intrapreneurship models must be differentiated by size, small or large organizations.
Some authors have focused on the innovation process that is intrapreneurship. Carrier (1997) went further by making resorted links between intrapreneurship and creativity. Similarly Vial (1995), developed a model of organizational innovation in large organizations that focuses on knowledge contradiction (individuals and groups) and how these combine in past time when developing creative activities.

\section{Empirical Analysis}

This is a quantitative survey based on a questionnaire developed from themes from preparatory research, the questionnaire was administered to 60 Tunisian intrapreneurs and exploitation of data was made using a software that allowed to descriptive statistics. This study allowed us to have a description of the factors that can stimulate intrapreneurship in Tunisian SMEs to raise difficulties in the steps of creation.

\subsection{Identification of the company}

Table 1: Identification of companies

\begin{tabular}{|l|l|}
\hline \multicolumn{1}{|c|}{ Variables } & \multicolumn{1}{c|}{ Results / features } \\
\hline $\begin{array}{l}\text { What is the legal } \\
\text { form of your } \\
\text { company? }\end{array}$ & $\begin{array}{l}\text { 30\% limited liability company (SARL) } \\
\text { (SUARL) } \\
17 \% \text { limited company (SA) } \\
10 \% \text { Company (SNC) }\end{array}$ \\
\hline $\begin{array}{l}\text { What's the } \\
\text { number of your } \\
\text { company's } \\
\text { business? }\end{array}$ & $\begin{array}{l}32 \% \text { Less than 10 million } \\
53 \% \text { From 10 million to 30 million } \\
15 \% \text { More than 30 million }\end{array}$ \\
\hline $\begin{array}{l}\text { How long has } \\
\text { your business } \\
\text { been in operation? }\end{array}$ & $\begin{array}{l}12 \% \text { Less than a year } \\
61 \% \text { From 1 to 5 years } \\
10 \% \text { From 6 to 10 years } \\
17 \% \text { between 26 and 35 years }\end{array}$ \\
\hline
\end{tabular}

The first results give information on the identification of businesses owned by Intrapreneurs we can see in our investigation that the companies studied are relatively young small size and legal form 43\% SUARL; Ltd. 30\%; SA $17 \%$ and $10 \%$ of SNC companies.

Most companies created by Intrapreneurs $85 \%$ have a turnover of 30 million, by $15 \%$ against only one turnover exceeds 30 million. Similarly $73 \%$ of the company creates are aged 5 years old and $27 \%$ are older than 6 years.

This trend, though the number of entrepreneurs can be explained by encouraging Tunisian government introduced programs and reforms to boost entrepreneurship at national and local level.

\subsection{Identification of intrapreneurs}




\section{International Journal of Science and Research (IJSR) \\ ISSN (Online): 2319-7064}

Index Copernicus Value (2013): 6.14 | Impact Factor (2015): 6.391

Table 2: Identification of intrapreneurs

\begin{tabular}{|c|l|}
\hline Variables & \multicolumn{1}{|c|}{ Results / features } \\
\hline What is your age? & $7 \%$ Under 25 \\
& $35 \%$ between 26 and 35 years \\
& $58 \%$ More than 35 years \\
\hline What is your family & $35 \%$ Single \\
situation? & $45 \%$ Married \\
& $8 \%$ Widow \\
& $12 \%$ Divorced \\
\hline What is your educational & Bachelor's 20\% less \\
level? & $18.75 \%$ Bachelor's +2 \\
& $28.75 \%+4$ Bachelor's \\
& $32.5 \%$ Bachelor's degree +5 more \\
\hline Professional experience & $35 \%$ Lower than 2 years \\
& $22.5 \%[2$ years; 5 years] \\
& $52.5 \%$ Greater than 5 years \\
\hline
\end{tabular}

The descriptive analysis of the sample reveals that on all entrepreneurs 35\% Single; Married 45\%; 8\% 12\% Divorced Widow, about $42 \%$ of designers are aged under 35 years, $58 \%$ of designers are aged more than 35 years. We can argue that the study population is relatively young, confirming that young people are more attracted to entrepreneurship. These individuals would therefore have acquired professional but also social experience. However, these mature present weaknesses (physical, psychological ...) which, as had advanced Kets de Vries, could strongly influence the entrepreneur, it is important to see young people at the top of the hierarchy.

It goes without saying, this table that all the young entrepreneurs are graduates of higher education with unequal proportions as to the duration of study certifying diplomas obtained. These graduates are in most cases, graduates of masters $28.75 \% ; 32.5 \%+5$ and more; Bachelor's $20 \%$ or less, +218.75 .

\subsection{Project financing}

Table 3: Distribution of businesses "project financing"

\begin{tabular}{|c|c|c|c|}
\hline \multirow{2}{*}{ To fund your } & Your personal savings & $\begin{array}{l}\text { Absolute } \\
\text { frequency }\end{array}$ & $\begin{array}{l}\text { Relative } \\
\text { frequency }\end{array}$ \\
\cline { 2 - 4 } $\begin{array}{c}\text { project you } \\
\text { use: }\end{array}$ & Your neighbors, family & 12 & $19 \%$ \\
\cline { 2 - 4 } & The banks & 27 & $20 \%$ \\
\cline { 2 - 4 } & Other financial institutions & 10 & $45 \%$ \\
\hline Total & & 60 & $16 \%$ \\
\hline
\end{tabular}

Our survey finds that the majority of entrepreneurs one resorts to a financial institution to finance its own project which justify $61 \%$ of designers has recourse to banks and other financial institutions by $39 \%$ against one resorts to personal savings and the entourage, family.

\subsection{Business Management}

Table 4: Distribution of businesses by the assets of an entrepreneur

\begin{tabular}{|c|c|c|c|}
\hline \multirow{2}{*}{\multicolumn{2}{|c|}{}} & $\begin{array}{c}\text { Absolute } \\
\text { frequency }\end{array}$ & $\begin{array}{c}\text { Relative } \\
\text { frequency }\end{array}$ \\
\hline What do you think & The personality & 6 & $10 \%$ \\
\cline { 2 - 4 } \begin{tabular}{c} 
the strengths of $\begin{array}{c}\text { contractor? } \\
\text { cony }\end{array}$ \\
\cline { 2 - 4 }
\end{tabular} & The initiative & 10 & $16,67 \%$ \\
\cline { 2 - 4 } & Appropriate training & 14 & $23,33 \%$ \\
\cline { 2 - 4 } & Other & 10 & $16,67 \%$ \\
\hline Total & & 60 & $100 \%$ \\
\hline
\end{tabular}

Table 04 shows that the assets of an entrepreneur varies investigated as it represents $10 \%$ to $17 \%$ the personality, the spirit of initiative $33 \%$ silver, $23 \%$ adequate training, and $17 \%$ other.

\section{Results and Interpretation of Linear Regression}

We will in the following present and interpret the results of multiple linear regression: for the dependent variable "intrapreneurship in Tunisian SMEs." We in our research model, five assumptions that bear on this variable. Thus, we present the sorties SPSS results of multiple regression variables.

\subsection{The regression of the dependent variable "entrepreneurship in Tunisian SMEs"}

\subsubsection{Identifying companies / intrapreneurship in Tunisian SMEs}

The table below shows the results of the regression analysis relating to the variable "identification of undertakings'

Table 5: Analysis of explanatory variable "corporate identification"

\begin{tabular}{|l|c|}
\hline \multicolumn{1}{|c|}{$\begin{array}{c}\text { Dependent variable } \\
\text { Independent Variable }\end{array}$} & $\begin{array}{c}\text { Intrapreneurship in } \\
\text { Tunisian SMEs }\end{array}$ \\
\hline IENTREPRISE $(\beta$ standardisé) & 0,361 \\
\hline T Student & 0,922 \\
\hline Signification & $0,116^{\text {ns }}$ \\
\hline
\end{tabular}

ns : non significatif à $p>0.05$

The results show that:

- The value of $\mathrm{t}$ student calculated $(\mathrm{t}=0.922)$ is $<\mathrm{t}$ theoretical student $(\mathrm{t}=1.96)$;

- Unilateral meaning is clearly greater than 0.05 .

The result is therefore that standardized $\beta$ is not significant. Thus, identification of business did not affect intrapreneurship in Tunisian SMEs and economic growth of the country in general: $\mathrm{H} 1$ is unaudited.

\subsubsection{Identification of entrepreneurs / entrepreneurship in Tunisian SMEs}

The results of the analysis of the explanatory variable

"Identifying entrepreneurs" have the following results:

Table 6: Analysis of explanatory variable "Identification of entrepreneurs'

\begin{tabular}{|l|c|}
\hline $\begin{array}{c}\text { Dependent variable } \\
\text { Independent Variable }\end{array}$ & $\begin{array}{c}\text { Intrapreneurship in } \\
\text { Tunisian SMEs }\end{array}$ \\
\hline IENTREPRENEUR ( $\beta$ standardisé) & 0,322 \\
\hline T de Student & 2,353 \\
\hline Signification unilateral & 0,023 \\
\hline
\end{tabular}

ns : non significatif à $\mathrm{p}>0.05$

He results show that;

Does the student is calculated value ( $>1.96)$;

Unilateral meaning is well below 0.05 .

It turns out that standardized $\beta$ is significant. Thus, identification of entrepreneurs or the executive profile has a significant and positive effect (standardized $\beta=0.023>0$ ) on intrapreneurship in Tunisian SMEs: H2 is verified. 


\section{International Journal of Science and Research (IJSR) \\ ISSN (Online): 2319-7064}

Index Copernicus Value (2013): 6.14 | Impact Factor (2015): 6.391

The significant influence of the profile of the leader on intrapreneurship in Tunisian SMEs and corporate growth reinforces the results of many works such as those of Ucbasaran et al.

Several recent studies of nascent entrepreneurs (Menzies et al., 2002) confirm the importance of the benefit of entrepreneurs in creating new businesses. They seek autonomy and independence, want to become their own boss and take initiatives in this direction. The result we have reached is in line with previous research that demonstrated the beneficial effect of need autonomy on the recognition of business opportunities (Davidsson, 1995; Engle et al., 1997; Burke, Fitzroy, and Nolan 2000 and Sweeney, 1982. Thus, the fact of being your own boss, to be independent and to work according to his own desire acts positively on intrapreneurship in Tunisian SMEs.

Even for the study of Carrier, (1993) shows the importance of entrepreneur profile, he noted that "authors that we articulated their concept of intrapreneurship around the individual who is the main actor, seems intrapreneurs consider as the main source of intrapreneurship in business.

\subsubsection{Project financing / entrepreneurship in Tunisian} SMEs

The results of the analysis of the explanatory variable "project financing" are summarized in the table below:

Table 7: Analysis explanatory variable "project financing"

\begin{tabular}{|l|c|}
\hline $\begin{array}{c}\text { Dependent variable } \\
\text { Independent Variable }\end{array}$ & $\begin{array}{c}\text { Intrapreneurship in } \\
\text { Tunisian SMEs }\end{array}$ \\
\hline Financing ( $\beta$ standardisé) & 0,398 \\
\hline T de Student & 3,075 \\
\hline Signification unilateral & 0,004 \\
\hline \multicolumn{2}{|c|}{ ns : non significatif à p >0.05 }
\end{tabular}

The results show that:

- The value of t student calculated is equal to 3.075> 1.96;

- Unilateral meaning is clearly less than 0.05

We can conclude that standardized $\beta$ is significant. Thus, financing a significant and positive effect (standardized $\beta=$ $0.398>0$ ) on economic growth and on intrapreneurship in Tunisian SMEs: H3 is verified. So funding carries one way or another influences on individuals who make up society. This hypothesis is verified in the context of the present study.

\subsubsection{Business management / entrepreneurship in} Tunisian SMEs

The results of the analysis of the explanatory variable "Identifying entrepreneurs" have the following results:

Table 8: Explanatory Analysis of the variable "business management"

\begin{tabular}{|l|c|}
\hline \multicolumn{1}{|c|}{$\begin{array}{c}\text { Dependent variable } \\
\text { Independent Variable }\end{array}$} & $\begin{array}{c}\text { Intrapreneurship in } \\
\text { Tunisian SMEs }\end{array}$ \\
\hline Management ( $\beta$ standardisé) & 0,366 \\
\hline T de Student & 2,776 \\
\hline Signification unilatérale & 0,008 \\
\hline
\end{tabular}

ns : non significatif à $\mathrm{p}>0.05$
We note that:

- The value of t student calculated is equal to 2.776> 1.96;

- The one-sided significance is considerably lower than 0.05 .

We can conclude that standardized $\beta$ is significant. Thus, business management has a significant and positive effect (standardized $\beta=0.366>0$ ) intrapreneurship in Tunisian SMEs: H4 is verified. Hence the company's management is regarded as the advantage and the major factor for entrepreneurs in Tunisian SMEs. As confirmed Shays and Pryor $(1993,42)$ argue that "for a company to remain competitive and proactive, its manager must be semiautonomous; believe that they have the freedom to make the new business initiative and be entrepreneurial. »

\subsection{Innovation, risk-taking, pro-business entrepreneurship in Tunisian SMEs}

\subsubsection{Innovation / intrapreneurship in Tunisian SMEs}

The results of the regression analysis of the variable "Innovation" are summarized in the table below:

Table 9: Analysis of explanatory variable "innovation"

\begin{tabular}{|l|c|}
\hline $\begin{array}{c}\text { Dependent variable } \\
\text { Independent Variable }\end{array}$ & $\begin{array}{c}\text { Intrapreneurship in } \\
\text { Tunisian SMEs }\end{array}$ \\
\hline Innovation $(\beta$ standardisé) & 0,329 \\
\hline T de Student & 2,147 \\
\hline Signification unilateral & 0,023 \\
\hline
\end{tabular}

ns : non significatif à $\mathrm{p}>0.05$

The results show that;

Does the student is calculated value (> 1.96);

Unilateral meaning is well below 0.05 .

It turns out that standardized $\beta$ is significant. Thus, innovation has a significant and positive effect (standardized $\beta=0.023>0$ ) on economic growth of the country: H5.1 is verified.

The significant influence of innovation on the quality of services received from companies reinforces the results of many works such as those of Ucbasaran et al.

\subsubsection{Taking risk / country's economic growth}

The table below shows the results of the regression analysis relating to the variable "risk taking"

Table 10: Analysis of explanatory variable "risk taking"

\begin{tabular}{|c|c|}
\hline $\begin{array}{c}\text { Dependent variable } \\
\text { Independent Variable }\end{array}$ & $\begin{array}{c}\text { Intrapreneurship in } \\
\text { Tunisian SMEs }\end{array}$ \\
\hline RisK taking $(\beta$ standardisé) & 0,361 \\
\hline T Student & 0,922 \\
\hline Signification & $0,116^{\mathbf{n s}}$ \\
\hline
\end{tabular}

ns : non significatif à $p>0.05$

The results show that:

- The value of $\mathrm{t}$ student calculated $(\mathrm{t}=0.922)$ is $<\mathrm{t}$ theoretical student $(\mathrm{t}=1.96)$;

- Unilateral meaning is clearly greater than 0.05 .

The result is therefore that standardized $\beta$ is not significant. Thus, the risk is generally regarded as a potential source of loss but also represent an opportunity for the company does not have an effect on growth and intrapreneurship in Tunisian SMEs in our context: H5.2 is unaudited. 


\section{International Journal of Science and Research (IJSR) \\ ISSN (Online): 2319-7064}

Index Copernicus Value (2013): 6.14 | Impact Factor (2015): 6.391

5.2.3 Pro-business / entrepreneurship in Tunisian SMEs The results of the regression analysis of the variable "Proactivity" are summarized in the following table:

Table 11: Analysis of explanatory variable "Proactivity"

\begin{tabular}{|c|c|}
\hline $\begin{array}{c}\text { Dependent variable } \\
\text { Independent Variable }\end{array}$ & $\begin{array}{c}\text { intrapreneurship in } \\
\text { Tunisian SMEs }\end{array}$ \\
\hline PRO ACTIVITY $(\beta$ standardisé) & $-0,165$ \\
\hline T de Student & $-1,180$ \\
\hline Signification unilateral & $0,244^{\mathbf{n s}}$ \\
\hline
\end{tabular}

ns : non significatif à $p>0.05$

The results show that:

- The value of $t$ is student calculated in absolute value equal to 1.180. Compared to the theoretical value of $t$ student $(\mathrm{t}$ $=1.96)$ at the $5 \%$ threshold, we find that the calculated $\mathrm{t}$ value $(<1.96)$;

- Unilateral meaning is clearly greater than 0.05 .

It therefore appears that standardized $\beta$ is not significant. Thus, improving pro-activity affects the success of their business has no significant effect on intrapreneurship in Tunisian SMEs and economic growth in our study context: H5.3 is unaudited.

\section{Conclusion}

As we can see, research on intrapreneurship work, although they allow seeing its great advantages in an organization, addressing some questions of its practical implementation (Morris and Trotter, 1990) and any difficulties in taking off. The research conducted to date has certainly allowed to know several effects of intrapreneurship, favorable and unfavorable factors has its presence as the link between practice and intrapreneurship several other aspects of management such as strategy, organizational psychology, human resource management, leadership or organizational culture. Intrapreneurship the dynamic has always been regarded as an avenue to foster the development of new products, new ways and for new markets. Over time, the use of intrapreneurship activities has become essential to stimulate the process of innovation in all activities and management functions within organizations.

This process cannot be achieved without difficulty. Various authors have highlighted the risks associated with the integration of intrapreneurship culture within an organization. We notice an increasing interest of researchers in recent decades for this research theme. Many studies, including empirical, have tried to find solutions for the realization of the ideal type of organization or intrapreneurship profile. Most researchers in entrepreneurship and intrapreneurship nevertheless consider that this objective is still far from being achieved. However many efforts converge towards this direction. We tried to account for these efforts and to draw attention to the fact that to stimulate intrapreneurship in organizations, it is necessary both to establish a conducive organizational context and select employees with a potential intrapreneurship.

Indeed, Tunisia is now in a critical place of transition following a revolution that has been at the origin of the Arab Spring and brought the country on the path of economic transformation and to succeed Tunisia faces major problems are unemployment and poverty which affects the youth in a country population is relatively young. Meanwhile, the Tunisian economy is characterized by economic fabric composed of traditional enterprise engaged in traditional sectors with low growth and low income generation opportunities; it must necessarily be open to technologies, products and new markets.

Admittedly, the Tunisian government introduced programs and reforms to stimulate entrepreneurship and intrapreneurship at national and local level. Access to finance and improved by the new seed capital funds and loan guarantees, start-ups are supported by new business incubators, training and coaching of entrepreneurs to improve their qualifications and skills in this domain. It is important that these measures be made accessible to all Tunisians.

\section{References}

[1] Allali, B. (2002). «Vision des dirigeants et internationalisation des PME : ébauche d'un cadre conceptuel», in Filion, L.J. et Simard, G. (éd.), L'entrepreneur et la PME face aux transformations au monde des affaires, Actes du CIFME 2002, École des HEC Montréal.

[2] Antoncic, B. (2001). «Intrapreneurship: Construct refinement and cross-cultural validation», Journal of Business Venturing, Vol. 16, No. 5, pp. 495.

[3] Beaucourt, C. \& Louart, P. (1998). «Aspects psychosociologiques d'un développement des potentiels humains» in Bournois, F. \& Roussillon, S. (éd.), Préparer les dirigeants de demain - Une approche internationale de la gestion des cadres à haut potentiel, Paris : Éditions d'Organisation

[4] Carrier, C. (1991). «Intrapreneurship et PME», Revue Internationale de Gestion, Vol.16, No. 4, pp. 2027.

[5] Carrier, C. (1992). L'intrapreneuriat dans la PME : une étude exploratoire du phénomène à partir des représentations des acteurs concernés. Thèse de doctorat en sciences de gestion, Université de Montpellier.

[6] Carrier, C. (1993). La littérature sur l'intrapreneurship: un discours polyphonique, Cahiers de recherche 93-09 de l'Université du Québec à TroisRivières, Groupe de recherche en économie et gestion des PME.

[7] Carrier, C. (1994). «La PME : incubateur ou «excubateur» d'intrapreneurs?», Communication présentée à la 39e Conférence annuelle mondiale du Congrès international de la petite entreprise, Strasbourg, 27-29 juin 1994.

[8] Carrier, C. (1994). «Intrapreneurship in large firms and SMEs: A comparative study» International Small Business Journal, Vol. 12, No. 3, pp. 54-59. Carrier, C. (1994c). Spécificités de l'intrapreneuriat en contexte de PME, Cahier de recherche numéro 94-03 de l'Université du Québec à Trois-Rivières, Groupe de recherche en économie et gestion des PME.

[9] Carrier, C. (1996). «Intrapreneurship in small businesses: An exploratory study», Entrepreneurship Theory and Practice, Vol. 21, No. 1, 1996. 


\section{International Journal of Science and Research (IJSR) \\ ISSN (Online): 2319-7064}

Index Copernicus Value (2013): 6.14 | Impact Factor (2015): 6.391

[10] Carrier, C. (2000). «L'Intrapreneuriat - A la recherche de complices innovants et entreprenants», in Verstraete, T. (dir.), Histoire d'entreprendre - Les réalités de l'entrepreneuriat, Caen : Éditions EMS, pp. 199- 210.

[11] Filion, L.J. (1989). «L'intrapreneurs : un visionnant», Revue Internationale des Petites et Moyennes Organisations, Vol. 5, No. 1, pp.22-33.

[12] Filion, L.J. (1999). D'employés à intrapreneurs, Cahier de recherche $n^{\circ}$ 99-03 de la Chaire d'entrepreneurship Maclean Hunter de l'école des HEC Montréal.

[13] Lombardi, D.N. (1990). «Intrapreneurial constituency management : A success profile», Hospital Materiel Management Quarterly, Vol. 11, No. 4, pp. 26.

[14] Torrès, O. (2000). «L'entrepreneuriat face à la globalisation», in Verstraete, T. (Dir.), Histoire d'entreprendre - Les réalités de l'entrepreneuriat, Paris : Éditions Management et Société (EMS), Collection Gestion en Liberté, pp. 67-88.

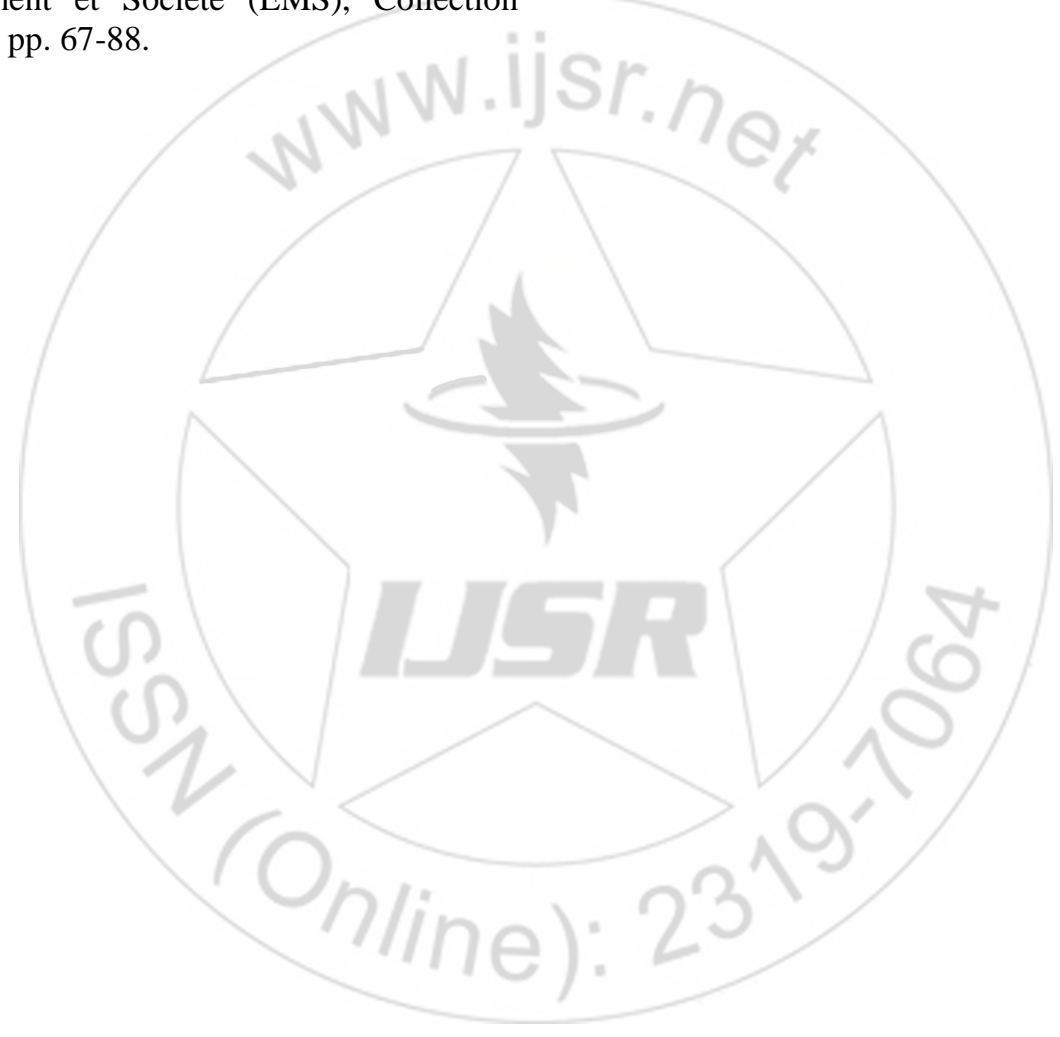

